\title{
Deskripsi Topik Pembicaraan yang Tidak Menyinggung Privasi Bagi Penutur Bahasa Jepang dan Penutur Bahasa Indonesia
}

\author{
SONDA SANJAYA*1, MUHAMAD KUSNENDAR ${ }^{2}$

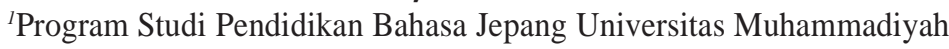 \\ Yogyakarta \\ Jl. Lingkar Selatan, Kasihan, Bantul, Yogyakarta 55183, Indonesia \\ E-mail: sonda.sanjaya@umy.ac.id Telp: +6285318952232
}

\begin{abstract}
ABSTRAK
Penelitian ini merupakan penelitian deskriptif kuantitatif yang bertujuan untuk mengetahui topik pembicaraan yang digunakan penutur bahasa Jepang dan penutur bahasa Indonesia yang tidak menyinggung privasi. Topik pembicaraan dibatasi pada topik yang digunakan kepada orang yang pertama kali dijumpai. Teknik yang digunakan pada penelitian ini adalah teknik survey dengan menggunakan angket sebagai instrumen penelitiannya. Jumlah responden penutur bahasa Jepang sebanyak 93 orang dan jumlah responden penutur bahasa Indonesia sebanyak 101 orang. Dari hasil analisis data ditemukan bahwa topik pembicaraan yang pernah digunakan penutur bahasa Jepang kepada orang yang pertama kali dijumpai adalah nama, hobi, asal daerah, cuaca, cara melewatkan liburan, tempat bekerja, berita atau isu terkini, keluarga, akun media sosial, tanggal lahir, mempunyai kekasih atau tidak, alamat surel, alamat tinggal, nomor telepon genggam, mempunyai anak atau tidak, status pernikahan, status pekerjaan atau kepegawaian, isi telepon genggam, gaji, isi dompet, kamar sendiri, dan isi komputer. Berbeda dengan penutur bahasa Jepang, penutur bahasa Indonesia menggunakan nama, tempat bekerja, asal daerah, alamat tinggal, hobi, status pekerjaan atau kepegawaian, keluarga, berita atau isu terkini, nomor telepon genggam, akun media sosial, mempunyai anak atau tidak, cara melewatkan liburan, status pernikahan, cuaca, alamat surel sebagai topik pembicaraan kepada orang yang pertama kali dijumpai. Dilihat dari keterkaitan topik pembicaraan dengan ranah privasi, topik pembicaraan penutur bahasa Jepang yang digunakan kepada orang yang pertama kali dijumpai namun tidak menyinggung privasi penutur bahasa Indonesia adalah nama, hobi, asal daerah, cuaca, cara melewatkan liburan, tempat bekerja, berita atau isu terkini, keluarga, akun media sosial, tanggal lahir, alamat surel, alamat tinggal, nomor telepon genggam, mempunyai anak atau tidak, dan status pekerjaan atau kepegawaian. Sedangkan topik pembicaraan penutur bahasa Indonesia kepada orang yang pertama kali dijumpai namun tidak menyinggung privasi penutur bahasa Jepang adalah nama, tempat bekerja, asal daerah, hobi, keluarga, berita atau isu terkini, mempunyai anak atau tidak, cara melewatkan liburan, dan cuaca.

Kata kunci : topik pembicaraan; orang yang pertama kali dijumpai; ranah privasi; penutur bahasa Jepang; penutur bahasa Indonesia
\end{abstract}




\begin{abstract}
This descriptive quantitative study aims at finding out conversational topics being talked about by Japanese and Indonesian speakers when they meet people for the first time. Additionally, this study also explores conversational topics among Japanese speakers, which are considered as non-private by Indonesian speakers. Furthermore, the conversational topics among Indonesian speakers, which are considered as non-private by Japanese speakers, were also investigated. To collect the data, survey technique was employed. 93 Japanese speakers and 101 Indonesian speakers voluntarily took part in this study. The data analysis revealed that the conversational topics among Japanese speakers, which have ever been talked about in their first contact included name, hobby, hometown, weather, vacation, workplace, current issues, family, social media accounts, birthday, relationship status, email address, address, mobile phone number, children, marital status, employment status, salary, as well as the content of their wallet, bedroom, mobile phone and computer. Meanwhile, the conversational topics among Indonesian speakers, which have ever been talked about in their first contact included name, workplace, hometown, address, hobby, employement status, family, current issues, mobile phone number, social media accounts, children, vacation, marital status, weather, and email address. In addition, conversational topics among Japanese speakers, which are considered as non-private by Indonesian speakers included name, hobby, hometown, weather, vacation, work place, current issues, family, social media accounts, birthday, email account, address, mobile phone number, children, and employment status. The conversational topics among Indonesian speakers, which are considered as non-private by Japanese speakers included name, workplace, hometown, hobby, family, current issues, children, vacation and weather. Keywords: conversational topics; the first contacts; privacy; communication; Japanese speakers; Indonesian speakers
\end{abstract}

\title{
I. PENDAHULUAN
}

Dalam kehidupan sehari-hari, manusia tidak luput dari kegiatan yang disebut komunikasi dan interaksi dengan sesama. Untuk melakukan komunikasi dan interaksi tersebut, seseorang memerlukan topik pembicaraan sehingga komunikasi lebih terarah dan interaksi pun dapat berjalan dengan lancar. Begitu pula saat menemukan seseorang yang pertama kali dijumpai terkadang ada suatu momen atau kesempatan untuk berkomunikasi walau komunikasi berlangsung singkat. Misalnya, saat menunggu antrean di rumah sakit, adakalanya mengajak penunggu antrean lain untuk berbicara. Dalam momen tersebut pun, perlu topik pembicaraan yang tepat agar komunikasi dan interaksi berjalan baik.

Dalam konteks komunikasi lintas budaya seperti halnya komunikasi penutur bahasa Indonesia dan penutur bahasa Jepang, topik pembicaraan menjadi hal penting untuk 
diperhatikan. Topik pembicaraan perlu menyesuaikan aspek gender, identitas orientasi seksual, identitas secara etnisitas, kewarganegaraan, bahkan status antara pembicara dengan lawan bicara. Jika topik pembicara sesuai dengan hal-hal tersebut, besar kemungkinan komunikasi akan berhasil terjalin (Martin \& Nakayama, 2004). Selain aspek-aspek tersebut, salah satu aspek lainnya yang perlu diperhatikan adalah apakah topik pembicaraan tersebut menyinggung privasi penutur bahasa Jepang atau tidak dan sebaliknya. Tidak jarang penutur bahasa Jepang menjumpai penutur bahasa Indonesia yang tiba-tiba ditanyai pertanyaan yang bagi penutur bahasa Indonesia hal biasa namun tidak bagi penutur bahasa Jepang, apalagi penutur bahasa Jepang tersebut baru pertama kali menjumpai penutur bahasa Indonesia tersebut.

Jika topik pembicaraan yang dilontarkan tidak tepat dan menyinggung privasi mitra tutur, kesalahpahaman dan ketidaklancaran dalam berkomunikasi menjadi hal yang sulit dihindari. Hal tersebut sejalan yang dinyatakan Darmastuti (2013:51-52) bahwa perbedaan latar belakang budaya menimbulkan masalah apabila penutur yang satu menggunakan simbol yang berbeda dengan simbol mitra tuturnya sehingga muncul perbedaan pemaknaan terhadap simbol tersebut. Hal ini sejalan dengan Sihabudin (2013) dan Sukmono \& Junaedi (2014) yang menyatakan bahwa pada proses komunikasi yang terjadi di antara orang yang berlatar belakang budaya sering terjadi kekeliruan dan semakin berbeda latar belakang budayanya semakin besar pula kemungkinan terjadinya kesalahpahaman dalam berkomunikasi. Jadi, jika simbol itu adalah topik pembicaraan, maka agar tidak terjadi kesalahpahaman dan kekeliruan penutur bahasa Indonesia dan penutur bahasa Jepang perlu memahami sosiokultur kedua bangsa. Selain itu, menurut Gass dan Varonis dalam Gudykunst dan Kim (1992), permasalahan komunikasi terjadi karena permasalahan pelafalan, tata bahasa, familiaritas topik yang didiskusikan, familiaritas dengan orang lain, familiaritas dengan bahasa asli orang lain, kefasihan bahasa orang lain, dan faktor sosial. Dengan demikian, pemahaman mengenai topik 
yang dibicarakan dan kondisi sosial menjadi hal yang sangat penting untuk diperhatikan dalam berkomunikasi.

Terdapat berbagai macam pendapat dari para ahli mengenai privasi. Moore (2008) berpendapat bahwa privasi bersifat kultural dan kebenarannya relatif. Bersifat kultural menunjukkan bahwa latar belakang budaya yang berbeda memengaruhi ruang lingkup privasi. Kebenarannya relatif menunjukkan bahwa sesuatu dianggap privasi bagi masyarakat yang satu namun tidak demikian bagi masyarakat lainnya.

Dalam bahasa Jepang tidak ditemukan padanan kata privasi. Meskipun tidak ada padanan katanya, konsep privasi tetap ditemukan dalam kehidupan masyarakat di Jepang (Mizutani dkk, 2004). Privasi merupakan gairaigo dari bahasa Inggris yang sering disebut puraibashii. Puraibashii atau privasi memiliki peran untuk melakukan proses pengaturan membuka dan menutup diri supaya seseorang yang memiliki rahasia atau informasi yang ingin dijaga dapat dikendalikan aksesibilitasnya sehingga dirinya tidak terganggu atau terancam orang lain. Hal ini sesuai dengan yang dinyatakan oleh Burgoon dkk (1989).

Sanjaya dan Kusnendar (2017) mengkaji tentang privasi dalam komunikasi masyarakat penutur bahasa Jepang dan penutur bahasa Indonesia di kalangan masyarakat pekerja. Penelitian tersebut baru menganalisis ruang lingkup privasi di kalangan masyarakat penutur bahasa Jepang dan penutur bahasa Indonesia. Pada penelitian ini, peneliti akan menganalisis topik pembicaraan yang digunakan kepada orang yang pertama kali dijumpai yang tidak menyinggung privasi penutur bahasa Jepang dan penutur bahasa Indonesia.

Penelitian ini merupakan lanjutan dari penelitian sebelumnya yang bertujuan untuk mengetahui topik pembicaraan yang digunakan penutur bahasa Jepang dan penutur bahasa Indonesia kepada orang yang pertama kali dijumpai, mengetahui topik pembicaraan yang digunakan penutur bahasa Jepang kepada orang yang pertama kali dijumpai namun tidak menyinggung privasi penutur bahasa Indonesia, dan mengetahui topik 
pembicaraan yang digunakan penutur bahasa Indonesia kepada orang yang pertama kali dijumpai namun tidak menyinggung privasi penutur bahasa Jepang.

\section{METODE PENELITIAN}

Penelitian ini merupakan penelitian kuantitatif deskriptif yang menganalisis dan mendeskripsikan topik pembicaraan yang digunakan kepada orang yang pertama kali dijumpai namun tidak menyinggung ranah privasi dalam komunikasi penutur bahasa Jepang dan penutur bahasa Indonesia di kalangan masyarakat pekerja (shakaijin). Teknik yang digunakan adalah teknik survey dengan menggunakan angket. Sampel diambil dengan teknik random sampling dengan responden dari penutur bahasa Jepang sebanyak 93 responden dan penutur bahasa Indonesia sebanyak 101 responden. Untuk mengukur jawaban responden, peneliti menggunakan skala likert dengan nilai 3 untuk "setuju", nilai 2 untuk nilai "ragu-ragu", dan nilai 1 untuk "tidak setuju".

\section{HASIL DAN PEMBAHASAN}

Peneliti menetapkan 22 topik pembicaraan yang diduga digunakan oleh penutur saat berbicara kepada orang yang pertama kali dijumpai. Dari 22 topik pembicaraan, pada penutur bahasa Jepang ditemukan satu topik pembicaraan sering digunakan kepada orang yang pertama kali dijumpai. Topik tersebut adalah nama, dalam hal ini bisa nama penutur maupun nama mitra tutur. Kemudian, dari 22 topik pembicaraan delapan topik pembicaraan kadang-kadang digunakan kepada orang yang pertama kali dijumpai yaitu hobi, asal daerah, cuaca, cara melewatkan liburan, tempat bekerja, berita atau isu terkini, keluarga, dan akun media sosial. Sedangkan 13 topik pembicaraan lainnya hanya sebatas pernah digunakan kepada orang yang pertama kali dijumpai. Topik tersebut adalah tanggal lahir, mempunyai kekasih atau tidak, alamat surel, alamat tinggal, nomor telepon genggam, mempunyai anak atau tidak, status pernikahan, status pekerjaan atau kepegawaian, isi telepon 
genggam, gaji, isi dompet, kamar sendiri, dan isi komputer atau laptop. Melihat perolehan data, bisa dikatakan bahwa topik pembicaraan yang paling banyak digunakan penutur bahasa Jepang kepada orang yang pertama kali dijumpai adalah nama. Untuk lebih jelas dapat dilihat pada tabel 1 di bawah ini.

TABEL 1 TOPIK PEMBICARAAN YANG DIGUNAKAN PENUTUR BAHASA JEPANG KEPADA ORANG YANG PERTAMA KALI DIJUMPAI

\begin{tabular}{lll}
\hline NO. & TOPIK PEMBICARAAN & KATEGORI \\
\hline 1 & Nama & Sering \\
2 & Hobi & Kadang-Kadang \\
3 & Asal Daerah & Kadang-Kadang \\
4 & Cuaca & Kadang-Kadang \\
5 & Cara Melewatkan Liburan & Kadang-Kadang \\
6 & Tempat Bekerja & Kadang-Kadang \\
7 & Berita atau Isu Terkini & Kadang-Kadang \\
8 & Keluarga & Kadang-Kadang \\
9 & Akun Media Sosial & Kadang-Kadang \\
10 & Tanggal Lahir & Pernah \\
11 & Mempunyai Kekasih atau Tidak & Pernah \\
12 & Alamat Surel & Pernah \\
13 & Alamat Tinggal & Pernah \\
14 & Nomor Telepon Genggam & Pernah \\
15 & Mempunyai Anak atau Tidak & Pernah \\
16 & Status Pernikahan & Pernah \\
17 & Status Pekerjaan atau Kepegawaian & Pernah \\
18 & Isi Telepon Genggam & Pernah \\
19 & Gaji & Pernah \\
20 & Isi Dompet & Pernah \\
21 & Kamar Sendiri & Pernah \\
22 & Isi Komputer atau Laptop & Pernah \\
\hline
\end{tabular}

Berbeda dengan penutur bahasa Jepang, topik pembicaraan yang digunakan penutur bahasa Indonesia kepada orang yang pertama kali dijumpai adalah nama, tempat bekerja, dan asal daerah. Nama sering digunakan penutur bahasa Jepang kepada 


\begin{tabular}{|c|c|c|}
\hline NO. & TOPIK PEMBICARAAN & KATEGORI \\
\hline 1 & Nama & Selalu \\
\hline 2 & Tempat Bekerja & Sering \\
\hline 3 & Asal Daerah & Sering \\
\hline 4 & Alamat Tinggal & Kadang-Kadang \\
\hline 5 & Hobi & Kadang-Kadang \\
\hline 6 & Status Pekerjaan atau Kepegawaian & Kadang-Kadang \\
\hline 7 & Keluarga & Kadang-Kadang \\
\hline 8 & Berita atau Isu Terkini & Pernah \\
\hline 9 & Nomor Telepon Genggam & Pernah \\
\hline 10 & Akun Media Sosial & Pernah \\
\hline 11 & Mempunyai Anak atau Tidak & Pernah \\
\hline 12 & Cara Melewatkan Liburan & Pernah \\
\hline 13 & Status Pernikahan & Pernah \\
\hline 14 & Cuaca & Pernah \\
\hline 15 & Alamat Surel & Pernah \\
\hline 16 & Tanggal Lahir & Tidak Pernah \\
\hline 17 & Mempunyai Kekasih atau Tidak & Tidak Pernah \\
\hline 18 & Gaji & Tidak Pernah \\
\hline 19 & Isi Komputer atau Laptop & Tidak Pernah \\
\hline 20 & Isi Telepon Genggam & Tidak Pernah \\
\hline 21 & Kamar Sendiri & Tidak Pernah \\
\hline 22 & Isi Dompet & Tidak Pernah \\
\hline
\end{tabular}

orang yang pertama kali dijumpai tetapi selalu digunakan penutur bahasa Indonesia kepada orang yang pertama kali dijumpai. Begitu pula dengan tempat bekerja dan asal daerah. Penutur bahasa Indonesia menggunakan kedua topik tersebut kepada orang yang pertama kali dijumpai dengan frekuensi sering sedangkan penutur bahasa Jepang menggunakan kedua topik tersebut dengan frekuensi kadang-kadang. Kemudian, pada penutur bahasa Indonesia dapat dilihat bahwa beberapa topik 
digunakan dengan frekuensi kadang-kadang seperti alamat tinggal, hobi, status pekerjaan atau kepegawaian, keluarga. Sedangkan topik mengenai berita atau isu terkini, nomor hp, akun media sosial, mempunyai anak atau tidak, cara melewatkan liburan, status pekerjaan, cuaca, dan alamat email termasuk ke dalam kategori pernah. Sedangkan topik pembicaraan lainnya seperti tanggal lahir, mempunyai kekasih atau tidak, gaji, isi komputer atau laptop, isi hp, kamar sendiri, dan isi dompet termasuk ke dalam kategori tidak pernah digunakan sebagai topik pembicaraan kepada orang yang pertama kali dijumpai. Untuk lebih jelas dapat dilihat pada tabel 2 .

Jika dilihat dari topik yang digunakan oleh penutur bahasa Jepang dan penutur bahasa Indonesia kepada orang yang pertama kali dijumpai, dapat dilihat persamaan dan perbedaannya. Persamaan yang terdapat pada kedua penutur adalah baik penutur bahasa Jepang maupun penutur bahasa Indonesia menggunakan nama sebagai topik pembicaraan yang digunakan kepada orang yang pertama kali dijumpai meskipun secara frekuensi nama tidak selalu digunakan oleh penutur bahasa Jepang seperti halnya penutur bahasa Indonesia yang selalu menggunakannya. Kemudian, topik pembicaraan mengenai hobi dan keluarga kadang-kadang digunakan oleh penutur bahasa Jepang dan penutur bahasa Indonesia sedangkan topik pembicaraan lainnya terdapat perbedaan secara frekuensi. Bahkan jika dilihat dari frekuensinya, dari 22 topik pembicaraan yang ada sekurangkurangnya pernah digunakan oleh penutur bahasa Jepang kepada orang yang pertama kali dijumpai sedangkan pada penutur bahasa Indonesia terdapat tujuh topik pembicaraan yang sama sekali tidak pernah digunakan. Untuk lebih detail bisa dilihat pada tabel 3.

Sebelum mengaitkan topik pembicaraan kepada orang yang pertama kali dijumpai dengan ranah privasi, kita perlu mengetahui ranah privasi dalam komunikasi di kalangan penutur bahasa Jepang dan penutur bahasa Indonesia. Ranah privasi kedua penutur bisa dilihat pada tabel 4 di bawah ini. 
VOL. 2 NO. 1

FEBRUARI 2018

TABEL 3 PERSAMAAN DAN PERBEDAAN TOPIK PEMBICARAAN YANG DIGUNAKAN PENUTUR BAHASA JEPANG DAN PENUTUR BAHASA INDONESIA KEPADA ORANG YANG PERTAMA KALI DIJUMPAI

\begin{tabular}{|c|c|c|c|c|}
\hline NO. & $\begin{array}{l}\text { TOPIK PEMBICARAAN } \\
\text { PENUTUR BAHASA } \\
\text { JEPANG }\end{array}$ & KATEGORI & $\begin{array}{l}\text { TOPIK } \\
\text { PEMBICARAAN } \\
\text { PENUTUR } \\
\text { BAHASA } \\
\text { INDONESIA }\end{array}$ & KATEGORI \\
\hline 1 & Nama & Sering & Nama & Selalu \\
\hline 2 & Hobi & Kadang-Kadang & Tempat Bekerja & Sering \\
\hline 3 & Asal Daerah & Kadang-Kadang & Asal Daerah & Sering \\
\hline 4 & Cuaca & Kadang-Kadang & Alamat Tinggal & Kadang-Kadang \\
\hline 5 & $\begin{array}{l}\text { Cara Melewatkan } \\
\text { Liburan }\end{array}$ & Kadang-Kadang & Hobi & Kadang-Kadang \\
\hline 6 & Tempat Bekerja & Kadang-Kadang & $\begin{array}{l}\text { Status Pekerjaan } \\
\text { atau } \\
\text { Kepegawaian }\end{array}$ & Kadang-Kadang \\
\hline 7 & Berita atau Isu Terkini & Kadang-Kadang & Keluarga & Kadang-Kadang \\
\hline 8 & Keluarga & Kadang-Kadang & $\begin{array}{l}\text { Berita atau Isu } \\
\text { Terkini }\end{array}$ & Pernah \\
\hline 9 & Akun Media Sosial & Kadang-Kadang & $\begin{array}{l}\text { Nomor Telepon } \\
\text { Genggam }\end{array}$ & Pernah \\
\hline 10 & Tanggal Lahir & Pernah & $\begin{array}{l}\text { Akun Media } \\
\text { Sosial }\end{array}$ & Pernah \\
\hline 11 & $\begin{array}{l}\text { Mempunyai Kekasih } \\
\text { atau Tidak }\end{array}$ & Pernah & $\begin{array}{l}\text { Mempunyai Anak } \\
\text { atau Tidak }\end{array}$ & Pernah \\
\hline 12 & Alamat Surel & Pernah & $\begin{array}{l}\text { Cara Melewatkan } \\
\text { Liburan }\end{array}$ & Pernah \\
\hline 13 & Alamat Tinggal & Pernah & $\begin{array}{l}\text { Status } \\
\text { Pernikahan }\end{array}$ & Pernah \\
\hline 14 & $\begin{array}{l}\text { Nomor Telepon } \\
\text { Genggam }\end{array}$ & Pernah & Cuaca & Pernah \\
\hline 15 & $\begin{array}{l}\text { Mempunyai Anak } \\
\text { atau Tidak }\end{array}$ & Pernah & Alamat Surel & Pernah \\
\hline 16 & Status Pernikahan & Pernah & Tanggal Lahir & Tidak Pernah \\
\hline 17 & $\begin{array}{l}\text { Status Pekerjaan atau } \\
\text { Kepegawaian }\end{array}$ & Pernah & $\begin{array}{l}\text { Mempunyai } \\
\text { Kekasih atau } \\
\text { Tidak }\end{array}$ & Tidak Pernah \\
\hline 18 & Isi Telepon Genggam & Pernah & Gaji & Tidak Pernah \\
\hline 19 & Gaji & Pernah & $\begin{array}{l}\text { Isi Komputer } \\
\text { atau Laptop }\end{array}$ & Tidak Pernah \\
\hline 20 & Isi Dompet & Pernah & $\begin{array}{l}\text { Isi Telepon } \\
\text { Genggam }\end{array}$ & Tidak Pernah \\
\hline 21 & Kamar Sendiri & Pernah & Kamar Sendiri & Tidak Pernah \\
\hline 22 & $\begin{array}{l}\text { Isi Komputer atau } \\
\text { Laptop }\end{array}$ & Pernah & Isi Dompet & Tidak Pernah \\
\hline
\end{tabular}


TABEL 4 RANAH PRIVASI DALAM KOMUNIKASI PENUTUR BAHASA JEPANG DAN PENUTUR BAHASA INDONESIA

\begin{tabular}{|c|c|c|c|c|}
\hline & TOPIK PEMBICARAAN & & TOPIK PEMBICARAAN & \\
\hline NO. & $\begin{array}{l}\text { PENUTUR BAHASA } \\
\text { JEPANG }\end{array}$ & KATEGORI & $\begin{array}{l}\text { PENUTUR BAHASA } \\
\text { INDONESIA }\end{array}$ & KATEGORI \\
\hline 1 & Alamat Tinggal & Privasi & Isi Dompet & Privasi \\
\hline 2 & $\begin{array}{l}\text { Nomor Telepon } \\
\text { Genggam }\end{array}$ & Privasi & $\begin{array}{l}\text { Isi Komputer atau } \\
\text { Laptop }\end{array}$ & Privasi \\
\hline 3 & Isi Telepon Genggam & Privasi & Isi Telepon Genggam & Privasi \\
\hline 4 & Alamat Surel & Privasi & Gaji & Privasi \\
\hline 5 & Gaji & Privasi & Kamar Sendiri & Privasi \\
\hline 6 & $\begin{array}{l}\text { Isi Komputer atau } \\
\text { Laptop }\end{array}$ & Privasi & $\begin{array}{l}\text { Mempunyai Kekasih } \\
\text { atau Tidak }\end{array}$ & Privasi \\
\hline 7 & Isi Dompet & Privasi & Status Pernikahan & Privasi \\
\hline 8 & Akun Media Sosial & Privasi & $\begin{array}{l}\text { Mempunyai Anak } \\
\text { atau Tidak }\end{array}$ & Ragu-Ragu \\
\hline 9 & $\begin{array}{l}\text { Status Pekerjaan atau } \\
\text { Kepegawaian }\end{array}$ & Privasi & Keluarga & Ragu-Ragu \\
\hline 10 & Tanggal Lahir & Privasi & $\begin{array}{l}\text { Nomor Telepon } \\
\text { Genggam }\end{array}$ & Ragu-Ragu \\
\hline 11 & Kamar Sendiri & Privasi & Tanggal Lahir & Ragu-Ragu \\
\hline 12 & $\begin{array}{l}\text { Mempunyai Kekasih } \\
\text { atau Tidak }\end{array}$ & Privasi & $\begin{array}{l}\text { Status Pekerjaan atau } \\
\text { Kepegawaian }\end{array}$ & Ragu-Ragu \\
\hline 13 & Status Pernikahan & Privasi & Alamat Surel & Ragu-Ragu \\
\hline 14 & Keluarga & Ragu-Ragu & Akun Media Sosial & Ragu-Ragu \\
\hline 15 & $\begin{array}{l}\text { Mempunyai Anak atau } \\
\text { Tidak }\end{array}$ & Ragu-Ragu & Alamat Tinggal & Ragu-Ragu \\
\hline 16 & Tempat Bekerja & Ragu-Ragu & $\begin{array}{l}\text { Cara Melewatkan } \\
\text { Liburan }\end{array}$ & $\begin{array}{l}\text { Bukan } \\
\text { Privasi }\end{array}$ \\
\hline 17 & Asal Daerah & Ragu-Ragu & Tempat Bekerja & $\begin{array}{l}\text { Bukan } \\
\text { Privasi }\end{array}$ \\
\hline 18 & Nama & Ragu-Ragu & Hobi & $\begin{array}{l}\text { Bukan } \\
\text { Privasi }\end{array}$ \\
\hline 19 & Hobi & Ragu-Ragu & Asal Daerah & $\begin{array}{l}\text { Bukan } \\
\text { Privasi }\end{array}$ \\
\hline 20 & $\begin{array}{l}\text { Cara Melewatkan } \\
\text { Liburan }\end{array}$ & Ragu-Ragu & Cuaca & $\begin{array}{l}\text { Bukan } \\
\text { Privasi }\end{array}$ \\
\hline 21 & Berita atau Isu Terkini & $\begin{array}{l}\text { Bukan } \\
\text { Privasi }\end{array}$ & Berita atau Isu Terkini & $\begin{array}{l}\text { Bukan } \\
\text { Privasi }\end{array}$ \\
\hline 22 & Cuaca & $\begin{array}{l}\text { Bukan } \\
\text { Privasi }\end{array}$ & Nama & $\begin{array}{l}\text { Bukan } \\
\text { Privasi }\end{array}$ \\
\hline
\end{tabular}

(Sanjaya \& Kusnendar, 2017)

Dalam hal topik pembicaraan yang digunakan penutur bahasa Jepang kepada orang yang pertama kali dijumpai dengan menghubungkan ranah privasi penutur bahasa Indonesia dalam komunikasi, dapat dilihat bahwa topik pembicaraan yang digunakan penutur bahasa Jepang sangat aman dan banyak yang tidak menyinggung ranah privasi penutur bahasa Indonesia. Dari 
VOL. 2 NO. 1

TABEL 5 HUBUNGAN TOPIK PEMBICARAAN PENUTUR BAHASA JEPANG DENGAN RANAH PRIVASI PENUTUR BAHASA INDONESIA

\begin{tabular}{|c|c|c|c|c|}
\hline \multirow{2}{*}{ NO. } & \multicolumn{2}{|c|}{ PENUTUR BAHASA JEPANG } & \multicolumn{2}{|c|}{ PENUTUR BAHASA INDONESIA } \\
\hline & Topik Pembicaraan & Frekuensi & Topik Pembicaraan & Kategori \\
\hline 1 & Nama & Sering & Nama & Bukan Privasi \\
\hline 2 & Hobi & Kadang-Kadang & Hobi & Bukan Privasi \\
\hline 3 & Asal Daerah & Kadang-Kadang & Asal Daerah & Bukan Privasi \\
\hline 4 & Cuaca & Kadang-Kadang & Cuaca & Bukan Privasi \\
\hline 5 & $\begin{array}{l}\text { Cara Melewatkan } \\
\text { Liburan }\end{array}$ & Kadang-Kadang & $\begin{array}{l}\text { Cara Melewatkan } \\
\text { Liburan }\end{array}$ & Bukan Privasi \\
\hline 6 & Tempat Bekerja & Kadang-Kadang & Tempat Bekerja & Bukan Privasi \\
\hline 7 & $\begin{array}{l}\text { Berita atau Isu } \\
\text { Terkini }\end{array}$ & Kadang-Kadang & $\begin{array}{l}\text { Berita atau Isu } \\
\text { Terkini }\end{array}$ & Bukan Privasi \\
\hline 8 & Keluarga & Kadang-Kadang & Keluarga & Ragu-Ragu \\
\hline 9 & Akun Media Sosial & Kadang-Kadang & Akun Media Sosial & Ragu-Ragu \\
\hline 10 & Tanggal Lahir & Pernah & Tanggal Lahir & Ragu-Ragu \\
\hline 11 & $\begin{array}{l}\text { Mempunyai Kekasih } \\
\text { atau Tidak }\end{array}$ & Pernah & $\begin{array}{l}\text { Mempunyai } \\
\text { Kekasih atau Tidak }\end{array}$ & Privasi \\
\hline 12 & Alamat Surel & Pernah & Alamat Surel & Ragu-Ragu \\
\hline 13 & Alamat Tinggal & Pernah & Alamat Tinggal & Ragu-Ragu \\
\hline 14 & $\begin{array}{l}\text { Nomor Telepon } \\
\text { Genggam }\end{array}$ & Pernah & $\begin{array}{l}\text { Nomor Telepon } \\
\text { Genggam }\end{array}$ & Ragu-Ragu \\
\hline 15 & $\begin{array}{l}\text { Mempunyai Anak } \\
\text { atau Tidak }\end{array}$ & Pernah & $\begin{array}{l}\text { Mempunyai Anak } \\
\text { atau Tidak }\end{array}$ & Ragu-Ragu \\
\hline 16 & Status Pernikahan & Pernah & Status Pernikahan & Privasi \\
\hline 17 & $\begin{array}{l}\text { Status Pekerjaan } \\
\text { atau Kepegawaian }\end{array}$ & Pernah & $\begin{array}{l}\text { Status Pekerjaan } \\
\text { atau Kepegawaian }\end{array}$ & Ragu-Ragu \\
\hline 18 & $\begin{array}{l}\text { Isi Telepon } \\
\text { Genggam }\end{array}$ & Pernah & $\begin{array}{l}\text { Isi Telepon } \\
\text { Genggam }\end{array}$ & Privasi \\
\hline 19 & Gaji & Pernah & Gaji & Privasi \\
\hline 20 & Isi Dompet & Pernah & Isi Dompet & Privasi \\
\hline $\begin{array}{l}21 \\
22\end{array}$ & $\begin{array}{l}\text { Kamar Sendiri } \\
\text { Isi Komputer atau } \\
\text { Laptop }\end{array}$ & $\begin{array}{l}\text { Pernah } \\
\text { Pernah }\end{array}$ & $\begin{array}{l}\text { Kamar Sendiri } \\
\text { Isi Komputer atau } \\
\text { Laptop }\end{array}$ & $\begin{array}{l}\text { Privasi } \\
\text { Privasi }\end{array}$ \\
\hline
\end{tabular}

22 topik pembicaraan, terdapat 15 topik pembicaraan yang tidak menyinggung ranah privasi penutur bahasa Indonesia. Topik pembicaraan tersebut adalah nama, hobi, asal daerah, cuaca, cara melewatkan liburan, tempat bekerja, berita atau isu terkini, keluarga, akun media sosial, tanggal lahir, alamat surel, alamat tinggal, nomor telepon genggam, mempunyai anak atau tidak, dan status pekerjaan atau kepegawaian. Untuk lebih detail dapat dilihat pada tabel 5 .

Jika topik yang digunakan penutur bahasa Indonesia kepada 


\begin{tabular}{|c|c|c|c|c|}
\hline \multirow{2}{*}{ NO. } & \multicolumn{2}{|c|}{ PENUTUR BAHASA INDONESIA } & \multicolumn{2}{|c|}{ PENUTUR BAHASA JEPANG } \\
\hline & Topik Pembicaraan & Frekuensi & Topik Pembicaraan & Kategori \\
\hline 1 & Nama & Selalu & Nama & Ragu-Ragu \\
\hline 2 & Tempat Bekerja & Sering & Tempat Bekerja & Ragu-Ragu \\
\hline 3 & Asal Daerah & Sering & Asal Daerah & Ragu-Ragu \\
\hline 4 & Alamat Tinggal & Kadang-Kadang & Alamat Tinggal & Privasi \\
\hline 5 & Hobi & Kadang-Kadang & Hobi & Ragu-Ragu \\
\hline 6 & $\begin{array}{l}\text { Status Pekerjaan } \\
\text { atau Kepegawaian }\end{array}$ & Kadang-Kadang & $\begin{array}{l}\text { Status Pekerjaan } \\
\text { atau Kepegawaian }\end{array}$ & Privasi \\
\hline 7 & Keluarga & Kadang-Kadang & Keluarga & Ragu-Ragu \\
\hline 8 & $\begin{array}{l}\text { Berita atau Isu } \\
\text { Terkini }\end{array}$ & Pernah & $\begin{array}{l}\text { Berita atau Isu } \\
\text { Terkini }\end{array}$ & Bukan Privasi \\
\hline 9 & $\begin{array}{l}\text { Nomor Telepon } \\
\text { Genggam }\end{array}$ & Pernah & $\begin{array}{l}\text { Nomor Telepon } \\
\text { Genggam }\end{array}$ & Privasi \\
\hline 10 & Akun Media Sosial & Pernah & Akun Media Sosial & Privasi \\
\hline 11 & $\begin{array}{l}\text { Mempunyai Anak } \\
\text { atau Tidak }\end{array}$ & Pernah & $\begin{array}{l}\text { Mempunyai Anak } \\
\text { atau Tidak }\end{array}$ & Ragu-Ragu \\
\hline 12 & $\begin{array}{l}\text { Cara Melewatkan } \\
\text { Liburan }\end{array}$ & Pernah & $\begin{array}{l}\text { Cara Melewatkan } \\
\text { Liburan }\end{array}$ & Ragu-Ragu \\
\hline 13 & Status Pernikahan & Pernah & Status Pernikahan & Privasi \\
\hline 14 & Cuaca & Pernah & Cuaca & Bukan Privasi \\
\hline 15 & Alamat Surel & Pernah & Alamat Surel & Privasi \\
\hline 16 & Tanggal Lahir & Tidak Pernah & Tanggal Lahir & Privasi \\
\hline 17 & $\begin{array}{l}\text { Mempunyai } \\
\text { Kekasih atau Tidak }\end{array}$ & Tidak Pernah & $\begin{array}{l}\text { Mempunyai } \\
\text { Kekasih atau Tidak }\end{array}$ & Privasi \\
\hline 18 & Gaji & Tidak Pernah & Gaji & Privasi \\
\hline 19 & $\begin{array}{l}\text { Isi Komputer atau } \\
\text { Laptop }\end{array}$ & Tidak Pernah & $\begin{array}{l}\text { Isi Komputer atau } \\
\text { Laptop }\end{array}$ & Privasi \\
\hline 20 & $\begin{array}{l}\text { Isi Telepon } \\
\text { Genggam }\end{array}$ & Tidak Pernah & $\begin{array}{l}\text { Isi Telepon } \\
\text { Genggam }\end{array}$ & Privasi \\
\hline 21 & Kamar Sendiri & Tidak Pernah & Kamar Sendiri & Privasi \\
\hline 22 & Isi Dompet & Tidak Pernah & Isi Dompet & Privasi \\
\hline
\end{tabular}

orang yang pertama kali dijumpai dikaitkan dengan ranah privasi penutur bahasa Jepang dalam komunikasi, dapat dilihat bahwa beberapa topik yang digunakan penutur bahasa Indonesia bersinggungan dengan ranah privasi penutur bahasa Jepang seperti topik alamat tinggal dan status pekerjaan atau kepegawaian. Meskipun secara frekuensi topik tersebut masuk ke dalam kategori kadang-kadang tapi topik tersebut masih cukup memungkinkan digunakan sebagai topik pembicaraan kepada 
orang yang pertama kali dijumpai. Sedangkan topik pembicaraan yang digunakan penutur bahasa Indonesia kepada orang yang pertama kali dijumpai namun tidak menyinggung ranah privasi penutur bahasa Jepang terdapat Sembilan yaitu nama, tempat bekerja, asal daerah, hobi, keluarga, berita atau isu terkini, mempunyai anak atau tidak, cara melewatkan liburan, dan cuaca. Untuk lebih memahami temuan ini bisa dilihat pada tabel 6 di bawah ini.

\section{PENUTUP}

Dari hasil analisis data, dapat disimpulkan bahwa topik pembicaraan yang digunakan penutur bahasa Jepang kepada orang yang pertama kali dijumpai banyak meskipun secara frekuensi kebanyakan termasuk ke dalam kategori kadang-kadang dan hanya pernah digunakan. Dari 22 topik pembicaaraan tersebut hanya nama yang sering digunakan kepada orang yang pertama kali dijumpai. Berbeda dengan penutur bahasa Jepang, penutur bahasa Indonesia lebih sedikit menggunakan topik pembicaraan kepada orang yang pertama kali dijumpai. Meski demikian, secara frekuensi penggunaannya lebih banyak daripada penutur bahasa Jepang. Bahkan pada penutur bahasa Indonesia ditemukan tujuh topik pembicaraan yang tidak pernah digunakan kepada orang yang pertama kali digunakan. Dilihat dari keterkaitan antara topik pembicaraan yang digunakan kepada orang yang pertama kali dijumpai dengan ranah privasi, bagi penutur bahasa Jepang topik yang digunakan kepada orang yang pertama kali dijumpai aman digunakan kepada penutur bahasa Indonesia yang pertama kali dijumpai karena hampir semua topik tidak menyinggung ranah privasi kecuali topik tentang keluarga dan akun media sosial yang dianggap antara privasi dan bukan privasi bagi penutur bahasa Indonesia. Sedangkan penutur bahasa Indonesia cenderung harus lebih berhati-hati karena dari topik pembicaraan yang digunakan namun tidak menyinggung ranah privasi penutur bahasa Jepang tergolong tidak banyak. Dengan demikian, dapat disimpulkan 
bahwa secara kuantitas topik pembicaraan penutur bahasa Jepang kepada orang yang pertama kali dijumpai lebih banyak daripada penutur bahasa Indonesia tapi secara frekuensi penggunaannya penutur bahasa Indonesia lebih sering daripada penutur bahasa Jepang. Selain itu, topik pembicaraan yang digunakan penutur bahasa Jepang kepada orang yang pertama kali dijumpai cenderung aman disampaikan kepada penutur bahasa Indonesia daripada topik pembicaraan penutur bahasa Indonesia kepada penutur bahasa Jepang.

\section{DAFTAR PUSTAKA}

Burgoon, J. K., Parrott, R., Le Poire, B. A., Kelley, D. L., Walther, J. B., \& Perry, D. (1989). Maintaining and restoring privacy through communication in different types of relationships. Journal of Social and Personal Relationships, 6(2), 131-158.

Gudykunst, W. B., Kim, Y. Y. (1992). Communcating with Strangers: An Apprach to Intercultural Communication. New York: McGraw-Hill.

Martin, J. N., \& Nakayama, T. K. (2004). Intercultural Communication in Context. New York: McGraw-Hill.

Mizutani, M., Dorsey, J., Moor, J. H., dkk. (2004). The internet and Japanese conception of privacy. Ethics and Information Technology, 6: 121-128.

Moore, A. (2008). Defining Privacy. Journal of Sociophilosophy, 39(3): 411-428. Sanjaya, S., \& Kusnendar, M. (2017). Deskripsi Ranah Privasi dalam Komunikasi Masyarakat Pekerja (Shakaijin) Penutur Bahasa Jepang dan Penutur Bahasa Indonesia. Prosiding Dinamika Perkembangan Bahasa Jepang di Indonesia (hlm. 180-186). Yogyakarta: Program Studi Pendidikan Bahasa Jepang

Sihabudin, A. (2013). Komunikasi Antarbudaya Satu Perspektif Multidimensi. Jakarta: Bumi Aksara.

Sukmono, F. G., Junaedi, F. (2014). Komunikasi Multikultur Melihat Multikulturalisme dalam Genggaman Media. Yogyakarta: Buku Litera. 